\title{
Creative self-realization of a future teacher-artist in the process of professional training at the university
}

\author{
M.S. Mikhalchenko ${ }^{1 *}, I . N$. Kovalenko ${ }^{2}$, and I.Yu. Kodenko ${ }^{3}$ \\ ${ }^{1}$ V.I. Vernadsky Crimean Federal University, Simferopol, Russia \\ ${ }^{2}$ V.I. Vernadsky Crimean Federal University, Simferopol, Russia \\ ${ }^{3}$ V.I. Vernadsky Crimean Federal University, Simferopol, Russia
}

\begin{abstract}
The article reveals the conceptual problems of creative selfrealization of future teachers-artists. The authors note that the level of readiness of future professionals to work depends on the formation of creative pedagogical potential at the university, which consists of several components, such as motivational-axiological, cognitive and manipulative. The article justifies the need for specialists in the field of artistic and aesthetic education, who are able to work effectively in the new socioeconomic conditions. It is possible to increase the effectiveness of the creative self-realization of future teachers-artists in the process of higher education by creating certain pedagogical conditions.
\end{abstract}

\section{A problem statement}

The urgency of the research topic is determined by the fact that the peculiarities of modern Russian society and market economy require the formation of a new type of specialist independent, mobile, creative, initiative and striving to improve professional skills. Among the most important issues of modern higher education a special place is occupied by the priorities of training specialists in the field of art education.

The level of development of modern psychological and pedagogical science, social preconditions and modern educational paradigms stimulate the emergence of creative and innovative ideas. A creative approach is an indispensable condition in the pedagogical process, an objective professional necessity in the activities of teachers, and therefore it is necessary to get teachers of the system of higher and postgraduate education ready for creative pedagogical activity, the main feature of which is the ability to work in conditions of choice of pedagogical positions, technologies, textbooks, content and forms of teaching.

The issue of self-realization has an interdisciplinary status. There are many definitions of this concept, but so far researchers have not come to a single point of view: some continue to believe that self-realization is a phenomenon caused by the inherent nature of human self-realization (O.G. Cleaver, I.V. Kosterina), some deny this point of view (E.A.

\footnotetext{
* Corresponding author: prof-ped.gpa@mail.ru
} 
Kolomiets, L.V. Ovcharenko) and, finally, others believe that self-realization is a form of self-expression and self-realization (I.B. Dermanova, T.V. Lugovskaya) [1].

The theory of self-realization is a key system-forming element of humanistic trends in Western psychology (A. Adler, A. Maslow, G. Allport, K. Rogers, E. Fromm). Humanistic psychology focuses on the problem of upbringing and development of a harmonious and capable personality, realizing its potential in the interests of personal and social growth to the maximum. The theory of self-realization is put forward as a method for solving this problem. The humanistic direction proceeds from the fact that a conscious desire to maximize one's human potential and realize it in real life for the benefit of society through self-realization is a necessary factor in the full development of a personality. Thus, according to representatives of the humanistic direction, the self-realization of the individual has social certainty.

K. Rogers notes that all actions are inspired and governed by some common motivation, which he calls the desire to achieve. It represents "an inherent tendency of the body to develop its ability to preserve and reveal personality" [2]. According to K. Rogers, the most important aspect of achieving a tendency is a person's desire for self-realization. The tendency towards self-actualization is the process by which a person, throughout his life, uses his abilities to become a full-fledged person.

I.V. Besedina, exploring self-realization in the hierarchy of human needs, believes that all human needs can be expressed in a hierarchy, starting with the physiological needs for air, food and water. Besides, there are four levels of psychological needs - safety, love, respect and self-realization [3]. Self-realization is the last and highest step in the hierarchy of human needs.

In one of her works, Ya.A. Uspenskaya defines self-realization as the desire of a person to become what one is capable of being, the desire to realize what is contained in a person's inner potential. Ya.A. Uspenskaya emphasizes that in the direction of self-realization, the choice in favor of development should be made by a person in the case of each choice, and that a person's refusal from the desire to realize his abilities is fraught with pathology neurological or mental disorders, somatic diseases, etc. Thus, according to Ya.A. Uspenskaya, self-realization is a process that involves the realization of a person's inner potential, which is initially laid down in him or her. This process is a natural manifestation of a person and is a necessary condition for human survival [4].

V.D. Shadrikov notes that self-realization rises to the level of a person's hyper-adaptive activity. But, according to the researcher, there is a cultural and historical range from selfrealization as an accompanying phenomenon to self-realization as the conscious existence of an individual. The modern concept of self-realization is developing mainly in the second direction. That is why, speaking about the process of self-realization, it is important to pay special attention to its motivational components, as well as to the specifics of the activity in which self-realization will take place. Although there are many theories, methods and points of view on the phenomenon of individual self-realization, the positions of various researchers are united by the understanding that the desire for self-realization is the main motive force of the personality [5].

Researchers of the processes and phenomena of self-realization in social and humanitarian disciplines note in their definitions the connection between self-realization and creativity. For example, D. Leontiev connects the question of self-realization with the question of the origin, nature and character of human creativity. He understood creative self-realization as one of the main motive forces of a developed personality, stimulating and directing its activity [6]. Therefore, the goal of self-realization is not only the satisfaction of the individual's personal needs, but also the general good of the society in which he lives and works. 
According to E.V. Galazhinsky, self-realization is manifested as a specific form in which the self-organization of an individual appears as an open mental system [7]. Particular attention is paid to the concept of "openness", which can be attributed to the main characteristics of a self-actualizing personality, striving for interaction and ready to acquire new life experience and knowledge as a result of this interaction.

Creative self-realization and professional competence are the goals of higher art and pedagogical education. The concept of competence as a subordination is a means of achieving self-realization, providing the basis for individual creative self-realization, an environment conducive to the manifestation of the main forces of students, personal, artistic and pedagogical abilities. Professional competence is considered by us as the teacher's possession of the necessary amount of knowledge, skills and abilities that determine his pedagogical activity, the formation of pedagogical communication and the personality of the teacher as a medium of certain values and pedagogical consciousness.

Art education is able to show students how artistic experience leads to individual selfrealization. The dynamics of the experience of artistic and pedagogical activity presupposes three stages of its comprehension:

- the first stage - based on mastering the experience of artistic practice, mastering the general picture of the world and past artistic experience;

- the second stage - the acquisition of personal experience of artistic creation, including subjective meaning, personal perception and personal choice of one's own beliefs and activities;

- the third stage - the use of one's own artistic experience in teaching, the ability to identify personal interests of students, their wishes and preferences in educational and artistic activities.

The process of art and creativity is specifically related to the process of self-realization: for an individual the success of the latter depends on the extent to which the completed composition coincides with his inner vision of the artistic image, that is, the subjective presentation of a creative idea coincides with the idea of an already formed visual form (a finished work of art). This condition can serve as the basis for the artistic and creative selfrealization of teachers. However, in order to create the "inner vision" and the "final result" of high quality, that is, to meet the requirements for both artists and teachers, it is necessary to use pedagogical conditions that contribute to the formation of disciplined competencies and access to artistic and pedagogical skills [8].

The professional competence of a teacher-artist consists of two components: artistic and creative and professional and pedagogical. These integral characteristics are mutually limited - the ability to realize artistic skills in the management of children's creativity is the basis of the teacher's professional and pedagogical ability. We determined that the creative self-realization of the teacher-artist is the process of transforming the subjective qualities of the personality into an external objective form of existence, the process of transferring of social experience to children on the basis of co-creation, aimed at development and selfrealization in the conditions of artistic and creative activity. The subjective qualities of the teacher's personality include: artistic ability, emotional-figurative perception, creative thinking, creative imagination and professional ability.

The training of a teacher of fine arts in the system of higher education presupposes professional pedagogical training of practitioners of art and creativity, as well as specialists. We believe that the professional training of a future art teacher is a process of forming his professional abilities on the basis of the unity of psychology and pedagogy, as well as artistic and creative directions [9].

The content of professional artistic and creative training includes various forms of work designed to form: 
- cultural and historical skills (study of the theory and history of arts of different eras and ethnic groups);

- artistic and practical skills (mastering the means of artistic expression of various types of art);

- artistic taste and evaluation criteria in the context of spiritual, moral and aesthetic ideals.

The main goal of training a teacher-artist is to form a creative personality of a person who has professional artistic knowledge, skills and abilities. At the same time, visual literacy is only an instrument by which the artist is obliged to act. The whole complex of artistic and visual skills acquired during training is focused on solving artistic problems, that is, it should be used in the creative process. Achieving the level of creative activity requires mastering professional skills, developing imagination, artistic and imaginative thinking, which is the compulsory condition for professional training in the field of art [1013].

\subsection{The objective of the work}

The empirical study was carried out in a group of students of the Federal State Autonomous Educational Institution of Higher Education "V.I. Vernadsky Crimean Federal University".

The tasks of the determination stage of the experimental search work include:

- criteria and indicators that determine the level of development of students' creative self-realization;

- development of diagnostic tools to determine the level of development of creative self-realization of students;

- to determine the initial level of development of creative self-realization among students;

- to get information about the peculiarities of the development of creative selfrealization among students.

In the course of the research we used the following research methods: analysis of the research problem in the philosophical, psychological and pedagogical literature, analysis of regulatory documents, systematization, comparison, forecasting, planning, generalization of pedagogical experience.

\section{Results of the research}

The evaluation of results: if the answer matches the answer contained in the key, then plus one point. The calculation of the total volume of integration: 9-13 - the initial level, 14-18 - medium, 19-27 - high (the range of integration according to the test of V.I. Petrushin is calculated in proportion to the range). The level of student's attitude to activities in the specialty also shows the level of his creative self-realization. The diagnostic map records the names, patrilineal lines of the discipline, as well as the main indicators of the level of development of students' creative self-realization (Table 1).

Table 1. Diagnostic card.

\begin{tabular}{|c|l|c|c|c|c|c|}
\hline \multirow{2}{*}{ № } & \multicolumn{1}{|c|}{ Full name } & \multicolumn{2}{c|}{$\mathbf{1}$ criterion } & \multicolumn{2}{c|}{$\mathbf{1}$ criterion } & Total \\
\cline { 3 - 6 } & & $\begin{array}{c}\mathbf{1} \\
\text { indicator }\end{array}$ & $\begin{array}{c}\mathbf{2} \\
\text { indicator }\end{array}$ & $\begin{array}{c}\mathbf{1} \\
\text { indicator }\end{array}$ & $\begin{array}{c}\mathbf{2} \\
\text { indicator }\end{array}$ & \\
\hline 1 & S. Mikhail & 1 & 2 & 2 & 2 & 7 \\
\hline 2 & P. Elizaveta & 2 & 2 & 1 & 1 & 6 \\
\hline 3 & T. Arina & 1 & 1 & 1 & 1 & 4 \\
\hline
\end{tabular}


Based on the results of preliminary research, 3 levels of development of creative selfrealization were identified: reproductive, productive and creative. The criteria for the level of development of creative self-realization can be divided into motives and types of activity, which together reflect the quality, results and positive dynamics of the student's development.

In order to find out the initial value of a certain indicator, we conducted an experimental search at the stage of job definition. To implement it, we used questionnaires based on the number of indicators and provided a 3-point scale that allowed us to define the level of each indicator. There are 3 levels (reproduction, production, creativity). Numerically, the amount of points for a level ranges from 1 to 3 points. In addition to clarifying the value of each indicator that determines the level of development of creative self-realization, it is necessary to characterize each level (Table 2).

Table 2. The level of development of creative self-realization of students and their features.

\begin{tabular}{|c|c|c|c|}
\hline \multirow[t]{3}{*}{ Indicators } & \multicolumn{3}{|c|}{ Levels of formation of creative self-realization } \\
\hline & Reproductive & Productive & Creative \\
\hline & \multicolumn{3}{|c|}{ The characteristics of levels } \\
\hline $\begin{array}{l}\text { Values - goals: } \\
\text { (personal and } \\
\text { semantic } \\
\text { development, } \\
\text { adequate self- } \\
\text { concept, } \\
\text { uniqueness and } \\
\text { originality of the } \\
\text { personality). }\end{array}$ & $\begin{array}{l}\text { Weak awareness of } \\
\text { oneself as a person. }\end{array}$ & $\begin{array}{l}\text { A gradual awareness } \\
\text { of oneself as a person. }\end{array}$ & $\begin{array}{l}\text { Personal and semantic } \\
\text { development } \\
\text { observed, an adequate } \\
\text { self-concept is formed. }\end{array}$ \\
\hline $\begin{array}{l}\text { Values- } \\
\text { relationships: } \\
\text { social activity; } \\
\text { safeness in the } \\
\text { group; interaction } \\
\text { and co-creation } \\
\text { with the teacher. }\end{array}$ & $\begin{array}{l}\text { There is no desire to } \\
\text { interact with pupils of } \\
\text { the collective and the } \\
\text { teacher. }\end{array}$ & $\begin{array}{l}\text { A gradual desire for } \\
\text { interaction with pupils } \\
\text { of the collective and } \\
\text { the teacher. }\end{array}$ & $\begin{array}{l}\text { The desire for } \\
\text { interaction with pupils } \\
\text { of the collective and the } \\
\text { teacher is clearly } \\
\text { expressed. }\end{array}$ \\
\hline
\end{tabular}

In order to improve the quality of the learning process, it is important to identify the main educational motivation of the student in order to realize the most valuable motivation fully and to displace negative motivation into the context. In order to find out the main motives (values-goals) of the educational activities of students we conducted a survey. It can be assumed that a group of students with educational and cognitive motivation will approach the study of academic disciplines most responsibly. The main motivation for learning is the motivation of "compulsion by parents". This motivation is expressed by 10 people. This topic belongs to the "Avoiding Trouble" motivational group, which suggests an immature attitude towards learning. In general, for all group metrics, we obtained the following results (Table 3). 
Table 3. Diagnostic results of experimental search work.

\begin{tabular}{|l|l|c|c|c|c|c|}
\hline \multirow{2}{*}{ № } & \multirow{2}{*}{ Full name } & \multicolumn{2}{|c|}{1 criterion } & \multicolumn{2}{c|}{ 1 criterion } & \multirow{2}{*}{ Total points } \\
\cline { 3 - 6 } & & $\begin{array}{c}1 \\
\text { indicator }\end{array}$ & $\begin{array}{c}\mathbf{2} \\
\text { indicator }\end{array}$ & $\begin{array}{c}1 \\
\text { indicator }\end{array}$ & $\begin{array}{c}\mathbf{2} \\
\text { indicator }\end{array}$ & \\
\hline 1 & S. Mikhail & 1 & 2 & 2 & 2 & 7 \\
\hline 2 & P. Elizaveta & 2 & 2 & 1 & 1 & 6 \\
\hline 3 & T. Arina & 1 & 1 & 1 & 1 & 4 \\
\hline 4 & E. Grigory & 1 & 1 & 1 & 1 & 4 \\
\hline 5 & E. Lev & 1 & 1 & 1 & 1 & 4 \\
\hline 6 & A. Arseny & 1 & 1 & 1 & 1 & 4 \\
\hline 7 & I. Masha & 1 & 1 & 1 & 1 & 4 \\
\hline 8 & S. Lizaveta & 1 & 1 & 1 & 1 & 4 \\
\hline 9 & T. Egor & 2 & 2 & 2 & 2 & 8 \\
\hline 10 & K. Alexandra & 1 & 2 & 1 & 1 & 5 \\
\hline 11 & Rozov Alexander & 1 & 2 & 1 & 1 & 5 \\
\hline 12 & I. Roman & 1 & 1 & 1 & 1 & 4 \\
\hline 13 & S. Anna & 2 & 2 & 1 & 2 & 7 \\
\hline 14 & B. Sonya & 1 & 1 & 2 & 1 & 5 \\
\hline 15 & T. Anna & 1 & 1 & 1 & 1 & 4 \\
\hline & Total points & 18 & 21 & 15 & 18 & 74 \\
\hline
\end{tabular}

As a result of the experimental search work, criteria, indicators and levels of development of students' creative self-realization were determined. We have identified the following criteria: motivation and independence. The following criteria are attributed to motivation: values-goals: (personal-semantic development, full-fledged self-concept, uniqueness of personality); values-relationships: social activities; safeness in groups; interaction with teachers and co-creation. Self-determination: the ability to set goals and make choices, plan life activities; acquire new sense and purport for future activities.

Creative self-realization of teachers is a factor that influences the pedagogical process of art education positively and determines the degree of its effectiveness and success. Proceeding from the fact that teachers-artists are aware of themselves in joint and independent creative activity with children, the analysis of the modern experience of literary and artistic education is carried out in two directions: vocational training and artistic creativity.

Researches in artistic and creative areas are based on creative concepts in philosophy, psychology and pedagogy. Creativity is defined as the highest form of activity and the key human activity for creating new material and spiritual values. Today the question of how to define the borderline area between creativity and self-realization, having defined the space in which they interact and converge, remains controversial.

The analysis of scientific and theoretical studies of native and foreign authors allows you to use creativity as a way of personal self-realization. The effectiveness of an individual's activity depends on his creative potential as an integral quality reflecting the need, readiness and possibilities of creative self-realization. Besides, the implementation of this activity depends on the internal needs of the individual. In this case, creativity becomes a process of self-realization of the human personality. Perhaps due to the research of scientists, these concepts can turn out to be the same. 
The process of creative self-realization of the future teacher-artist assumes the following interrelated directions: mastering professional skills in the unity of teaching pedagogical and artistic creativity; mastering the skills and abilities of students in artistic activity, mastering the forms, methods, techniques and means of teaching children; the ability to reveal and develop their own personality, their skills, as well as the ability to form subjective needs, realized by children in creativity. Hence, preparation for creative selfrealization of a teacher-artist is a process of future specialist's purposeful and conscious mastering the basics of professional competence, pedagogical and artistic skills with an orientation towards the development and self-realization of children in the conditions of artistic and pedagogical education. The ensuring of the complex interaction of these components is the main direction of training teachers - the creative self-realization of artists. Professional self-determination and creative self-realization are the main stages of the professional and personal formation and development of a teacher, his movement to the heights of professionalism, the quality of teaching and pedagogical maturity.

\section{Conclusions}

The main conclusions of the study:

1. In pedagogics "self-realization" is defined as one of the goals of upbringing, which includes helping the individual to achieve positive opportunities, the disclosure of temperament and abilities. The main task of the teacher-artist is to make art a space for possible creative self-realization of a person. The implementation of this task lies in the aesthetic education of children by means of art and artistic pedagogy.

2. The creative self-realization of a future teacher-artist is the process of transforming the subjective qualities of a person into an external objective form of existence, transferring social experience to children on the basis of co-creation, aimed at development and selfrealization in the conditions of artistic and creative activity.

3. The preparation of creative self-realization of teachers-artists is a process of purposeful and conscious mastering of basic professional knowledge, skills and abilities of future specialists, due to the integration of artistic creativity and vocational pedagogical training, with a focus on the development and self-realization of children in conditions of art education.

4. The structural-meaningful model of the development of creative self-realization of future teachers-artists is a holistic mechanism in which all components are closely interconnected and subordinated to the general goal of the research - the creation of conditions that ensure the formation of a universal ability for self-realization as a trait of personality manifested in artistic and pedagogical activity.

5. The effectiveness of the process of training future teachers for creative selfrealization is ensured by the implementation of a complex of organizational and pedagogical conditions (the formation of sustainable professional interests; management of diploma projects based on co-creation; organization of extracurricular activities of students; pedagogical practice in the system of additional education institutions; introduction of national and regional components into practice training and thematic special courses).

\section{References}

1. L.M. Mitina, Psychology of Labor and Professional Development of Teachers, 320 (2017)

2. K. Rogers, A Look at Psychotherapy. Becoming a Human Being, 478 (1994) 
3. I.V. Besedina, Formation of the Creative Potential of Future Architects in Professional Education, 170 (2017)

4. Ya.A. Uspenskaya, Pedagogical Opportunities for Realizing the Creative Potential of University Students, Bulletin of N.I. Lobachevsky State University of Nizhny Novgorod, 6, 35-37 (2018)

5. V.D. Shadrikov, Abilities, Gifts, Talent, 7-21 (2001)

6. D.A. Leontiev, Self-Realization and Human Essential Forces, Psychology with a Human Face: A Humanist Perspective in Post-Soviet Psychology, 156-176 (1997)

7. E.V. Galazhinsky, The problem of Levels of Human Self-Realization: Value-Semantic Context, Value Foundations of Psychological Science and the Psychology of Values, 123-147 (2008)

8. O.A. Abdullina, General Pedagogical Training of Teachers in the System of Higher Pedagogical Education, 141 (2017)

9. E.A. Shmareva, Psychological Support of the Creative Development of Junior Schoolchildren by Means of Recreational Swimming, 21 (2018)

10. D.B. Bogoyavlenskaya, Psychology of Creative Abilities, 320 (2016)

11. O.M. Shentsova, Professional Self-Determination and Formation of a Future Architect, 181-186 (2019)

12. O.M. Shentsova, Developing Interest in Learning by Creating an Emotionally Comfortable Educational Environment, Open Education, 6, 92-104 (2018)

13. I. Sigad, Self-Realization: a Realistic Goal?, Educational Practice and Theory, 18, $17-$ $28(2018)$ 